\title{
HMGI-C and HMGI(Y) Immunoreactivity Correlates with Cytogenetic Abnormalities in Lipomas, Pulmonary Chondroid Hamartomas, Endometrial Polyps, and Uterine Leiomyomas and is Compatible with Rearrangement of the HMGI-C and HMGI(Y) Genes
}

\author{
G. Tallini, R. Vanni, G. Manfioletti, B. Kazmierczak, G. Faa, P. Pauwels, \\ J. Bullerdiek, V. Giancotti, H. Van Den Berghe, and P. Dal Cin
}

Department of Pathology (GT), Yale University School of Medicine, New Haven, Connecticut; Dipartimento di Scienze Applicate ai Biosistemi (RV) and Dipartimento di Citomorfologia (GF), University of Cagliari, Cagliari, Italy; Dipartimento di Biochimica (GM, VG), Biofisica e Chimica delle Macromolecole, University of Trieste, Trieste, Italy; Center for Human Genetics \& Genetic Counseling (BK, JB), University of Bremen, Bremen, Germany; Department of Pathology (PP), Stichting PAMM, Eindhoven, The Netherlands; The Center for Human Genetics (HVDB), University of Leuven, Leuven, Belgium; Department of Pathology (PDC), Brigham and Women's Hospital, Boston, Massachusetts

\begin{abstract}
SUMMARY: High-mobility group (HMG) proteins are nonhistone nuclear proteins that play an important role in the regulation of chromatin structure and function. HMGI-C and $\mathrm{HMGI}(\mathrm{Y})$ are members of the HMGl family of HMG proteins, and their expression in adult tissues generally correlates with malignant tumor phenotypes. However, $\mathrm{HMGl}-\mathrm{C}$ and $\mathrm{HMGI}(\mathrm{Y})$ dysregulation as a result of specific rearrangements involving $12 q 15$ and $6 \mathrm{p} 21$, the respective chromosomal sites in which the HMGl-C and $H M G I(Y)$ genes are located, is also identified in a variety of common benign mesenchymal tumors, such as lipomas and uterine leiomyomata. The general prevalence of $\mathrm{HMGI}-\mathrm{C}$ and $\mathrm{HMGI}(\mathrm{Y})$ protein expression and its correlation with chromosomal alterations in these benign tumors are unknown. We analyzed 95 human tumors (20 lipomas, 21 pulmonary chondroid hamartomas, 26 uterine leiomyomata, and 28 endometrial polyps) representing a selection of the benign lesions in which karyotypic alterations involving the chromosomal regions $12 \mathrm{q} 15$ and $6 \mathrm{p} 21$ are frequently detected. All cases were successfully karyotyped and some of them analyzed by fluorescent in situ hybridization with probes spanning the HMGI-C and HMGI(Y) genes. The results of this study demonstrate that expression of $\mathrm{HMGl}-\mathrm{C}$ or $\mathrm{HMGI}(\mathrm{Y})$ is a common occurrence in lipomas, pulmonary chondroid hamartomas, leiomyomata, and endometrial polyps; that it correlates with $12 \mathrm{q} 15$ and $6 \mathrm{p} 21$ chromosomal alterations $(p<0.001)$; and that it is compatible with rearrangement of the HMGI-C and HMGI(Y) genes. The expression pattern and cellular localization of the immunoreactivity support the view that in biphasic lesions composed of a mixture of both stromal and epithelial cells, such as pulmonary chondroid hamartoma and endometrial polyps, the mesenchymal component is the site of the HMGl genetic alterations. (Lab Invest 2000, 80:359-369).
\end{abstract}

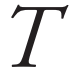
he chromosomal regions $12 q 15$ and 6 p21 are frequently involved in the karyotypic alterations observed in a variety of benign human tumors, such as

This study was supported in part by the Belgium Interuniversity Poles of Attraction Program (initiated by the Belgium State, Prime Minister's office, Science Policy Programming) and by the Assessorato Igiene e Sanita, Regione Autonoma Sardegna. VDBH was supported by FWO, Belgium. $M G$ and $G V$ were supported by Associazione Italiana per la Ricerca sul Cancro, Milano, Italy and by Ministero della Ricerca Scientifica e Tecnologica, Roma, Italy (cofinanziamenti N. 9706274625 e 9806279300 Address reprint requests to: Dr. G. Tallini, Department of Pathology, Yale New Haven Hospital, Rm EP2-608, 20 York Street, New Haven, CT 06510. Fax: 203-737-2922; E mail: tallini@yale.edu pulmonary chondroid hamartomas, lipomas, uterine leiomyomata, and endometrial polyps (Mitelman, 1998). All of these are characterized by abnormal proliferation of mesenchymal cells and include some of the most common tumors occurring in our species (eg, lipoma and uterine leiomyoma). HMGI-C and HMGI(Y) are members of the HMGI family of "highmobility group" (HMG) proteins. They act as architectural transcription factors and are commonly expressed in embryonal cells (Chiappetta et al, 1996; Hirning-Folz et al, 1998), in transformed cells with a malignant phenotype (Berlingieri et al, 1995; Bussemakers et al, 1991; Giancotti et al, 1987; 1989; Ram et al, 1993), and in a variety of human cancers (Bandiera 
et al, 1998; Chiappetta et al, 1995; 1998; Fedele et al, 1996; Rogalla et al, 1997; Rommel et al, 1997; Tamimi et al, 1993). HMGI-C and HMGI(Y) genes are located at 12q15 (Wanschura et al, 1995) and 6p21 (Friedmann et al, 1993), respectively. HMGl-C is not expressed in normal adult mouse (Manfioletti et al, 1991) or human tissues (Rogalla et al, 1996), whereas $\mathrm{HMGI}(\mathrm{Y})$ is only expressed at very low levels (Chiappetta et al, 1996).

Given the association of HMGI-C and HMGI(Y) with a transformed malignant phenotype, the recent identification of HMGI-C and HMGI(Y) as candidate tumor genes for a variety of benign neoplasms with specific chromosomal alterations at 12q15 (Schoenmakers et al, 1995) and 6p21 came somewhat as a surprise. HMGI-C dysregulation has been shown in lipomas (Ashar et al, 1995; Schoenmakers et al, 1995), pulmonary chondroid hamartomas (Kazmierczak et al, 1996b), uterine leiomyomas (Kazmierczak et al, 1995a; Schoenberg Fejzo et al, 1996), endometrial polyps (Dal Cin et al, 1998b; Wanschura et al, 1997), and in other tumor types featuring 12q15 karyotypic abnormalities (Kazmierczak et al, 1995b; 1998a; Schoenmakers et al, 1995; Staats et al, 1996). These tumors, moreover, often feature distinct subsets with 6p21 chromosomal changes, and disregulated HMGI(Y) expression has also been identified in lipomas (Tkachenko et al, 1997), pulmonary chondroid hamartomas (Xiao et al, 1997), uterine leiomyoma (Williams et al, 1997), and endometrial polyps (Kazmierczak et al, 1998b). Despite this experimental evidence linking chromosomal rearrangements involving $12 \mathrm{q} 15$ and $6 \mathrm{p} 21$ with $\mathrm{HMGI}-\mathrm{C}$ and $H M G I(Y)$ dysregulation, it is unclear however, whether these chromosomal changes are as a rule associated with increased levels of HMGI-C or $\mathrm{HMGI}(\mathrm{Y})$ proteins and whether there is a definite correlation between aberrant protein expression and the cytogenetic abnormalities. Previous results have suggested such a correlation for adipose tissue tumors (Tallini et al, 1997). We have therefore furthered our investigations to include the analysis of additional cases of lipomas as well as of a series of pulmonary chondroid hamartomas and of uterine leiomyomas. All tumors were investigated by conventional cytogenetic analysis and some of them by fluorescence in situ hybridization (FISH) with probes for HMGI-C and HMGI(Y) (Kazmierczak et al, 1996c; Schoenmakers et al, 1995). In the absence of suitable samples for Western blot analysis, immunohistochemistry was selected to detect HMGI-C and HMGI(Y) protein expression because it offers the advantage of in situ tissue discrimination. The objectives of the study were to determine for lipomas, pulmonary chondroid hamartomas, uterine leiomyomas, and endometrial polyps: a) the prevalence of $\mathrm{HMGI}-\mathrm{C}$ and $\mathrm{HMGI}(\mathrm{Y})$ protein (over)expression in these tumors; b) the existence of any correlation with the cytogenetic changes; and c) the tissue localization of the cells exhibiting (over)expression.

\section{Results}

The data in Tables 1-4 allow for a correlation of immunohistochemical reactivity for HMGI-C and $\mathrm{HMGI}(\mathrm{Y})$ with cytogenetic and FISH analysis in the various individual tumors. Overall, HMGI-C and $\mathrm{HMGI}(\mathrm{Y})$ immunoreactivity (Fig. 1) was present in 36 of $42(85.7 \%)$ and in 19 of $20(95.0 \%)$ of the tumors with $12 q 15$ or 6 p21 chromosomal alterations and/or HMGI gene rearrangement demonstrated by $\mathrm{FISH}$, respectively (Fig. 2). HMGI-C and HMGI(Y) immunoreactivity was observed in 9 of $53(17.0 \%)$ and in 16 of 75 $(21.3 \%)$ of the tumors without cytogenetic or FISH evidence for HMGI-C or HMGI(Y) gene rearrangement,

Table 1. Correlation Between Karyotypic Alterations, FISH, and Immunohistochemical Reactivity in 20 Lipomas

\begin{tabular}{|c|c|c|c|c|}
\hline Case & Karyotypic alterations & FISH & HMGI-C & $\operatorname{HMGI}(Y)$ \\
\hline $1 \mathrm{~L}$ & $\mathrm{t}(3 ; 12)(q 27 ; q 15)$ & HMGI-C & + & + \\
\hline $2 \mathrm{~L}$ & $\mathrm{t}(6 ; 12)(q 11 ; p 13)$ & Neg & - & - \\
\hline $3 \mathrm{~L}$ & None & ND & - & - \\
\hline $4 \mathrm{~L}$ & $\mathrm{t}(13 ; 14)(q 34 ; q 13)$ & ND & - & - \\
\hline $5 \mathrm{~L}$ & $\mathrm{t}(8 ; 12)(q 22 ; q 15)$ & HMGI-C & + & - \\
\hline $6 \mathrm{~L}$ & None & ND & - & - \\
\hline $7 \mathrm{~L}$ & $-Y, t(6 ; 14 ; 13)(p 11 ; q 32 ; q 11),+8$ & $\mathrm{HMGI}(\mathrm{Y})$ & - & + \\
\hline $8 \mathrm{~L}$ & $\mathrm{t}(13 ; 12)(q 27 ; q 15)$ & HMGI-C & + & - \\
\hline $9 \mathrm{~L}$ & $\mathrm{t}(4 ; 12)(\mathrm{q} 28 ; q 15)$ & HMGI-C & + & - \\
\hline $10 \mathrm{~L}$ & None & Neg & - & - \\
\hline $11 \mathrm{~L}$ & None & ND & - & + \\
\hline $12 \mathrm{~L}$ & None & ND & - & - \\
\hline $13 \mathrm{~L}$ & None & ND & + & - \\
\hline $14 \mathrm{~L}$ & $\mathrm{t}(2 ; 6)(q 36 ? ; p 21)$ & ND & - & + \\
\hline $15 \mathrm{~L}$ & None & ND & + & - \\
\hline $16 \mathrm{~L}$ & $\mathrm{t}(1 ; 12 ; 14)(q 23 ; q 15 ; q 24)$ & ND & + & - \\
\hline $17 \mathrm{~L}$ & $\mathrm{t}(2 ; 12)(q 35 ; q 15)$ & ND & + & - \\
\hline $18 \mathrm{~L}$ & $\mathrm{t}(3 ; 12)(\mathrm{q} 28 ; q 14-15)$ & ND & + & - \\
\hline $19 \mathrm{~L}$ & $\mathrm{t}(1 ; 12 ; 6)(p 32 ; q 15 ; p 21), \operatorname{del}(13)(q 12 q 22)$ & ND & - & + \\
\hline $20 \mathrm{~L}$ & $\mathrm{t}(9 ; 12 ; 13)(\mathrm{q} 22 ; \mathrm{q} 14-15 ; \mathrm{q} 12)$ & ND & + & - \\
\hline
\end{tabular}


Table 2. Correlation Between Karyotypic Alterations, FISH, and Immunohistochemical Reactivity in 21 Pulmonary Chondroid Hamartomas

\begin{tabular}{|c|c|c|c|c|}
\hline Case & Karyotypic alterations & FISH & $\mathrm{HMGI}-\mathrm{C}$ & HMGI(Y) \\
\hline $1 \mathrm{P}$ & None & HMGI-C & + & - \\
\hline $2 P$ & None & HMGI-C & + & - \\
\hline $3 P$ & $\operatorname{del}(12)(q 15-f r 23)$ & $\mathrm{HMGI}-\mathrm{C}$ & + & + \\
\hline $4 \mathrm{P}$ & $\operatorname{der}(6) t(6 ; 8)(p 21.3 ; q 12$ or 13$), \operatorname{der}(14) t(6 ; 14)(p 21.3 ; q 24)$ & HMGI(Y) & - & + \\
\hline $5 P$ & $\operatorname{der}(14) t(12 ; 14)(q 15 ; q 24)$ & HMGI-C & - & - \\
\hline $6 P$ & $\operatorname{inv}(12)(q 15 q ?)$ & HMGI-C & + & - \\
\hline $7 \mathrm{P}$ & $\begin{array}{l}\operatorname{der}(2) \mathrm{t}(2 ; 12)(\mathrm{p} 23 ; q 15), \operatorname{der}(12) \mathrm{t}(2 ; 12)(\mathrm{q} 33 ; q 15) \\
\quad \operatorname{der}(2) \mathrm{t}(2 ; 7)(q 33 ; q 36), \operatorname{der}(7) \mathrm{t}(2 ; 7)(\mathrm{p} 23 ; q 36)\end{array}$ & HMGI-C & + & - \\
\hline $8 \mathrm{P}$ & $\begin{array}{l}\operatorname{der}(11) \mathrm{t}(11 ; 17)(q 14 ; \mathrm{p} 11.2), \operatorname{der}(17) \mathrm{t}(12 ; 17)(\mathrm{q} 22 ; \mathrm{p} 11.2) \\
\operatorname{der}(12) \mathrm{t}(11 ; 12)(\mathrm{q} 14 ; \mathrm{q} 15), \operatorname{ins}(15 ; 12)(\mathrm{q} 22 ; \mathrm{q} 15-22)\end{array}$ & HMGI-C & + & - \\
\hline $9 \mathrm{P}$ & $\operatorname{ins}(12 ; 12)(q 15 ; q 13-15), \operatorname{inv}(12)(p ? q ?)$ & HMGI-C & + & + \\
\hline $10 \mathrm{P}$ & $\begin{array}{l}\mathrm{t}(3 ; 12)(\mathrm{q} 27 ; \mathrm{q} 15), \operatorname{der}(10) \operatorname{add}(10)(\mathrm{p} 15) \mathrm{t}(10 ; 21)(\mathrm{q} 21 ; \mathrm{q} 21), \\
\quad \operatorname{der}(21) \mathrm{t}(10 ; 21)(\mathrm{q} 21 ; \mathrm{q} 21)\end{array}$ & $\mathrm{HMGI}-\mathrm{C}$ & + & + \\
\hline $11 \mathrm{P}$ & $\mathrm{t}(6 ; 10)(\mathrm{p} 21.3 ; \mathrm{q} 22.3)$ & HMGI(Y) & - & + \\
\hline $12 \mathrm{P}$ & $t(12 ; 12 ; 16)(p 12 ; q 15 ; p 12$ or $p 13.1)$, del(22)(q12 or $q 13)$ & HMGI-C & - & - \\
\hline $13 \mathrm{P}$ & $\operatorname{der}(14) t(12 ; 14)(q 15 ; q 24)$ & HMGI-C & - & - \\
\hline $14 \mathrm{P}$ & $\begin{array}{l}\text { ins }(1 ; 7)(q 24.3 ; q 22 q 36), \operatorname{add}(2)(q 33), ? \operatorname{der}(6) \\
\quad t(X ; 4)(q 31.1 ; q 27)\end{array}$ & HMGI-C & + & + \\
\hline $15 P$ & $\begin{array}{l}\operatorname{der}(10) t(10 ; 12)(p 15 ; p 13.1) \\
\quad \operatorname{der}(12) \operatorname{del}(12)(p 13.1) \operatorname{inv}(12)(p 13.1 q 15)\end{array}$ & HMGI-C & + & - \\
\hline $16 \mathrm{P}$ & None & HMGI-C & + & - \\
\hline $17 \mathrm{P}$ & None & Neg & - & - \\
\hline $18 \mathrm{P}$ & None & Neg & - & - \\
\hline $19 \mathrm{P}$ & None & Neg & + & + \\
\hline $20 \mathrm{P}$ & None & Neg & - & - \\
\hline $21 \mathrm{P}$ & None & $\mathrm{Neg}$ & - & - \\
\hline
\end{tabular}

respectively. Conversely, HMGI-C and HMGI(Y) immunoreactivity was not detectable in 6 of $42(14.3 \%)$ and in 1 of $20(5.0 \%)$ of the tumors with $12 q 15$ or $6 p 21$ chromosomal alterations and/or HMGl gene rearrangement demonstrated by $\mathrm{FISH}$, respectively. Lesions with genetic alterations at 12 q15 were associated with $\mathrm{HMGI}-\mathrm{C}$ expression and those with alterations at $6 \mathrm{p} 21$ with $\mathrm{HMGl}(\mathrm{Y})$ expression, regardless of whether the tumor was a pulmonary chondroid hamartoma, a lipoma, a uterine leiomyoma, or an endometrial polyp ( $p<0.001$ ) (Fisher's exact test).

\section{Lipoma}

In lipomas immunohistochemical reactivity was visualized in the adipocyte nuclei (Fig. 1a). As shown in Table 1, of the nine cases with cytogenetic alterations at $12 \mathrm{q} 15$, eight were positive for HMGI-C. FISH confirmed rearrangement of the HMGI-C gene in five cases. The two cases with karyotypic alterations at $6 \mathrm{p} 21$ were positive for $\mathrm{HMGI}(\mathrm{Y})$, including one case featuring both 12q15 and 6p21 karyotypic alterations (19L). In the latter case, no significant HMGI-C reactivity was seen. Of the seven cases with normal karyotype, two were positive for HMGl-C, and one was positive for HMGI(Y) by immunohistochemistry. In none of these cases were FISH data available for correlation with the immunohistochemistry results. One of the three cases with karyotypic changes not involving $12 q 15$ or $6 p 21$, a spindle cell lipoma with chromosomal translocations involving 6p11 (7L), was positive for $\mathrm{HMGI}(\mathrm{Y})$ by immunohistochemistry, and involvement of HMGI(Y) was confirmed by FISH. The association of karyotypic alterations at 12q15 and/or HMGI-C rearrangement detected by FISH with positive immunohistochemical HMGl-C expression was significant ( $p=0.005$ ), as was that of karyotypic alterations at 6p21 and/or HMGI(Y) FISH results with positive immunohistochemical $\mathrm{HMGI}(\mathrm{Y})$ expression $(p=0.001)$.

\section{Pulmonary Chondroid Hamartoma}

In pulmonary chondroid hamartomas, immunohistochemical reactivity for either $\mathrm{HMGI}-\mathrm{C}$ or $\mathrm{HMGI}(\mathrm{Y})$ was predominantly located in the nuclei of adipocytes, cartilage cells, or stromal cells (Fig. 1c). However, there were occasional positive cells also in the epithelial component of the tumor, regardless of whether the case was eventually scored as positive or negative for HMGI-C or HMGI(Y). Focal immunoreactivity for $\mathrm{HMGI}-\mathrm{C}$ and $\mathrm{HMGI}(\mathrm{Y})$, respectively, was seen in the pneumocytes of one of seven and two of seven samples of non-neoplastic lung tissue used as controls. As shown in Table 2, of the 14 cases with karyotypic alterations at $12 \mathrm{q} 15$ and/or HMGl-C rearrangement detected by $\mathrm{FISH}, 11$ were positive for $\mathrm{HMGl}-\mathrm{C}$ by immunohistochemistry, including four cases that co-expressed both HMGI-C and HMGI(Y). The remaining three cases were negative for HMGI-C 
Table 3. Correlation Between Karyotypic Alterations, FISH, and Immunohistochemical Reactivity in 26 Uterine Leiomyomas

\begin{tabular}{|c|c|c|c|c|}
\hline Case & Karyotypic alterations & FISH & HMGI-C & $\operatorname{HMGI}(Y)$ \\
\hline $1 \mathrm{M}$ & $\mathrm{t}(6 ; 14)(\mathrm{p} 21 ; \mathrm{q} 24)$ & $\operatorname{HMGI}(\mathrm{Y})$ & - & + \\
\hline $2 \mathrm{M}$ & $\mathrm{t}(6 ; 10 ; 16)(\mathrm{p} 21 ; \mathrm{q} 22 ; \mathrm{p} 13)$ & $\operatorname{HMGI}(Y)$ & - & + \\
\hline $3 \mathrm{M}$ & None & Neg & - & - \\
\hline $4 \mathrm{M}$ & $\mathrm{t}(12 ; 14)(\mathrm{q} 15 ; \mathrm{q} 24)$ & HMGI-C & + & + \\
\hline $5 \mathrm{M}$ & $\mathrm{t}(1 ; 2)(\mathrm{q} 32 ; \mathrm{q} 13),-3 p s u \operatorname{dic}(3 ; 4)(\mathrm{q} 21 ; \mathrm{p} 15)$ & ND & - & + \\
\hline $6 \mathrm{M}$ & $\operatorname{del}(4)(p 11)$ & Neg & - & - \\
\hline $7 \mathrm{M}$ & $-1, \operatorname{der}(5), t(1 ; 5)(p 22 ; p 13),+r$ & ND & - & + \\
\hline $8 \mathrm{M}$ & None & ND & - & + \\
\hline $9 \mathrm{M}$ & $t(12 ; 14)(q 15 ; q 24)$ & HMGI-C & + & - \\
\hline $10 \mathrm{M}$ & $\operatorname{del}(3)(q 12 ; q 25)$ & Neg & - & - \\
\hline $11 \mathrm{M}$ & $t(9 ; 12)(q 31 ; q 14-15)$ & HMGI-C & + & - \\
\hline $12 \mathrm{M}$ & $\mathrm{t}(12 ; 14)(\mathrm{q} 15 ; \mathrm{q} 24)$ & HMGI-C & + & - \\
\hline $13 \mathrm{M}$ & $\operatorname{der}(1) t(1 ; ? 7)(p 32 ; q 21), \operatorname{add}(6)(q 21),+r$ & Neg & - & - \\
\hline $14 \mathrm{M}$ & $\mathrm{t}(12 ; 14)(\mathrm{q} 15 ; \mathrm{q} 24)$ & HMGI-C & + & - \\
\hline $15 \mathrm{M}$ & $7 q-, t(12 ; 14)(q 15 ; q 24)$ & HMGI-C & - & - \\
\hline $16 \mathrm{M}$ & None & Neg & - & - \\
\hline $17 \mathrm{M}$ & $\operatorname{add}(6)(p 21)$ & $\mathrm{HMGI}(\mathrm{Y})$ & - & + \\
\hline $18 \mathrm{M}$ & None & ND & - & - \\
\hline $19 \mathrm{M}$ & None & ND & - & - \\
\hline $20 \mathrm{M}$ & $\mathrm{t}(6 ; 9)(\mathrm{p} 21 ; q 13.3)$ & $\operatorname{HMGI}(Y)$ & - & + \\
\hline $21 \mathrm{M}$ & $\operatorname{del}(7)(q 22 q 32), t(12 ; 14)(q 15 ; q 24)$ & HMGI-C & + & - \\
\hline $22 \mathrm{M}$ & None & Neg & - & - \\
\hline $23 \mathrm{M}$ & $\mathrm{t}(10 ; 12)(q 22 ; q 13)$ & HMGI-C & + & - \\
\hline $24 \mathrm{M}$ & $t(12,14)(q 15 ; q 24)$ & HMGI-C & + & - \\
\hline $25 \mathrm{M}$ & $\operatorname{der}(9) t(9 ; 12)(q 22 ; q 15)$ & HMGI-C & + & - \\
\hline $26 \mathrm{M}$ & $t(12,14)(q 14-15 ; q 24)$ & HMGI-C & + & - \\
\hline
\end{tabular}

and HMGI(Y). The two cases with karyotypic alterations at $6 \mathrm{p} 21$ and $H M G I(Y)$ rearrangement by FISH were scored positive for HMGI(Y) immunohistochemistry (Figs. 1c, and 2, c and d). One of the five cases with normal karyotype and negative FISH analysis was positive for both HMGI(Y) and HMGI-C by immunohistochemistry. The association of karyotypic alterations at $12 \mathrm{q} 15$ and/or HMGI-C rearrangement detected by FISH with positive immunohistochemical HMGI-C expression was significant $(p=0.016)$. There was a trend for karyotypic alterations at $6 \mathrm{p} 21$ and $\mathrm{HMGI}(Y)$ rearrangement detected by FISH with positive immunohistochemical HMGI(Y) expression $(p=0.100)$.

\section{Uterine Leiomyoma}

In leiomyomas immunohistochemical reactivity was seen in the nuclei of smooth muscle cells (Fig. 1e). Focal immunoreactivity, particularly for HMGI(Y), was observed in rare nuclei of myometrial cells in the areas surrounding the leiomyoma. As shown in Table 3, of the 11 cases with karyotypic alterations at $12 \mathrm{q} 15$ and/or HMGI-C rearrangement detected by FISH, 10 were positive for HMGI-C by immunohistochemistry, including one case which co-expressed both HMGI-C and $\mathrm{HMGI}(\mathrm{Y})$.

All four cases with cytogenetic alterations at $6 \mathrm{p} 21$ and $H M G I(Y)$ rearrangement by FISH scored positive for $\mathrm{HMGI}(Y)$ immunohistochemistry. One of the six cases with a normal karyotype was positive for
HMGI(Y). Of the five cases with karyotypic changes not involving $12 \mathrm{q} 15$ or $6 \mathrm{p} 21$, two cases were positive for HMGI(Y) immunohistochemistry. The association of karyotypic alterations at 12q15 and/or HMGI-C rearrangement detected by FISH with positive immunohistochemical HMGI-C expression was significant $(p<0.001)$, as was that of karyotypic alterations at 6 p21 and/or HMGI(Y) FISH results with positive immunohistochemical HMGI(Y) expression ( $p=0.005)$.

\section{Endometrial Polyp}

In endometrial polyps immunohistochemical reactivity for either $\mathrm{HMGl}-\mathrm{C}$ or $\mathrm{HMGI}(\mathrm{Y})$ was predominantly located in the nuclei of stromal cells (Fig. 1g). However, positive cells for $\mathrm{HMGI}(\mathrm{Y})$ and less frequently for $\mathrm{HMGl}-\mathrm{C}$ were commonly observed in the nuclei of the endometrial glands both inside and outside of the polyp and regardless of whether the case was eventually scored as positive or negative for HMGI-C or HMGI(Y). At least focal HMGI-C and HMGI(Y) immunoreactivity was observed in 3 of 10 and 7 of 10 endometrial control samples of normal karyotype, respectively. HMGI protein expression was usually seen in those endometrial glands exhibiting proliferative features. As shown in Table 4, of the eight cases with karyotypic alterations at 12q15 and/or HMGI-C rearrangement detected by $\mathrm{FISH}$, seven were positive for HMGI-C by immunohistochemistry, including two cases that co-expressed HMGI-C and HMGI(Y). 
Table 4. Correlation Between Karyotypic Alterations, FISH, and Immunohistochemical Reactivity in 28 Endometrial Polyps

\begin{tabular}{|c|c|c|c|c|}
\hline Case & Karyotypic alterations & FISH & $\mathrm{HMGI}-\mathrm{C}$ & $\operatorname{HMGI}(Y)$ \\
\hline $1 \mathrm{E}$ & None & Neg & - & - \\
\hline $2 \mathrm{E}$ & None & HMGI-C & + & + \\
\hline $3 \mathrm{E}$ & None & Neg & + & - \\
\hline $4 \mathrm{E}$ & $\mathrm{t}(6 ; 8)(p 10 ; q 10)$ & HMGI(Y) & - & + \\
\hline $5 \mathrm{E}$ & $\mathrm{t}(8 ; 12)(q 11 ; q 15)$ & HMGI-C & + & - \\
\hline $6 \mathrm{E}$ & None & $\mathrm{HMGI}-\mathrm{C}$ & - & - \\
\hline 7 & $-6, \operatorname{add}(11)(q 21),+r$ & HMGI(Y) & - & + \\
\hline $8 \mathrm{E}$ & $\operatorname{inv}(12)(p 13 q 15)$ & HMGI-C & + & + \\
\hline $9 \mathrm{E}$ & None & ND & + & - \\
\hline $10 \mathrm{E}$ & $\mathrm{t}(12 ; 14)(\mathrm{q} 15 ; \mathrm{q} 24-25)$ & HMGI-C & + & - \\
\hline $11 \mathrm{E}$ & None & Neg & + & - \\
\hline $12 \mathrm{E}$ & $t(1 ; 6)(p 32 ; p 21)$ & HMGI(Y) & - & + \\
\hline $13 \mathrm{E}$ & $\mathrm{t}(6 ; 7)(\mathrm{p} 21 ; \mathrm{p} 15)$ & $\operatorname{HMGI}(\mathrm{Y})$ & - & + \\
\hline $14 \mathrm{E}$ & Non clonal abnormalities, + dmin & HMGI-C & + & - \\
\hline $15 \mathrm{E}$ & $\mathrm{t}(12 ; 14)(q 15 ; q 24)$ & HMGI-C & + & - \\
\hline $16 \mathrm{E}$ & None & ND & + & + \\
\hline $17 \mathrm{E}$ & $\mathrm{t}(2 ; 6)(q 35 ; \mathrm{p} 21)$ & HMGI(Y) & - & + \\
\hline $18 \mathrm{E}$ & $\mathrm{t}(3 ; 6 ; 12)(q 13 ; q 25 ; q 14-15)$ & HMGI-C & + & - \\
\hline $19 \mathrm{E}$ & None & ND & - & - \\
\hline $20 \mathrm{E}$ & None & ND & + & - \\
\hline $21 \mathrm{E}$ & $\mathrm{t}(6 ; 6 ; 10)(q 21 ; p 21 ; q 22)$ & ND & - & - \\
\hline $22 \mathrm{E}$ & $t(6 ; 14)(p 21 ; q 24)$ & $\mathrm{HMGI}(\mathrm{Y})$ & + & + \\
\hline $23 \mathrm{E}$ & $\mathrm{t}(6 ; 14)(\mathrm{p} 21 ; q 24)$ & HMGI(Y) & - & + \\
\hline $24 \mathrm{E}$ & None & ND & - & + \\
\hline $25 \mathrm{E}$ & $\mathrm{t}(6 ; 19)(\mathrm{p} 21 \mathrm{q} 13)$ & $\mathrm{HMGI}(\mathrm{Y})$ & - & + \\
\hline $26 \mathrm{E}$ & $\mathrm{t}(6 ; 11)(\mathrm{p} 21 ; \mathrm{q} 13)$ & HMGI(Y) & - & + \\
\hline $27 \mathrm{E}$ & None & ND & - & + \\
\hline $28 \mathrm{E}$ & $\mathrm{t}(1 ; 6)(\mathrm{p} 32 ; \mathrm{p} 21), \mathrm{t}(6 ; 9)(\mathrm{q} 13-14 ; \mathrm{q} 22)$ & $\mathrm{HMGI}(\mathrm{Y})$ & - & + \\
\hline
\end{tabular}

Ten of the eleven cases with cytogenetic alterations at $6 \mathrm{p} 21$ and/or $\mathrm{HMGI}(Y)$ rearrangement detected by FISH were positive for HMGI(Y) by immunohistochemistry, including one case that also co-expressed HMGI-C. Of the nine cases with normal karyotype and negative FISH results, four were positive for HMGI-C alone, two were positive for $\mathrm{HMGl}(\mathrm{Y})$ alone, one was positive for both HMGI(Y) and HMGI-C. The association of karyotypic alterations at $12 \mathrm{q} 15$ and/or HMGI-C rearrangement detected by FISH with positive immunohistochemical HMGI-C expression was significant ( $p=0.011)$, as was that of karyotypic alterations at $6 \mathrm{p} 21$ and/or HMGI(Y) FISH results with positive immunohistochemical HMGI( $Y$ ) expression $(p=0.002)$.

\section{Discussion}

The molecular changes underlying HMGI-C and $H M G I(Y)$ gene dysregulation in benign tumors seem to be consistent with two general mechanisms already identified in other tumor types. These involve either intragenic rearrangements with chimeric fusion products between two different genes, which are juxtaposed as a consequence of the chromosomal translocation, or rearrangements with breakpoints located outside the coding region of the gene, which result in transcriptional activation due to the fusion of enhancer sequences in the translocation partners (Rabbitts,
1994). Several chimeric mRNAs involving HMGI-C have been identified, such as HMGI-C/LPP (lipoma preferred partner) in lipomas and pulmonary chondroid hamartomas with the $t(3 ; 12)$ (Petit et al, 1996), $\mathrm{HMGI}-\mathrm{C} / \mathrm{ALDH} 2$ (mitochondrial aldehyde dehydrogenase) in a uterine leiomyoma with a paracentric inversion of chromosome 12 (Kazmierczak et al, 1995a), and HMGI-C/RTVLH (retrovirus like human sequences) in pulmonary chondroid hamartomas and uterine leiomyomas with seemingly normal karyotypes (Kazmierczak et al, 1996a). All of these rearrangements involve the large (140 kb) third intron of HMGI-C and result in the loss of the $3^{\prime}$ portion of the gene coding for the protein-binding domains of HMGI-C. It is important to recognize that even if the fusion products listed above are in frame, some of the rearranged genes contribute very few amino acids to the chimeric products (Kazmierczak et al, 1995a). It has therefore been suggested that the minimal requirement for tumorigenesis would be HMGI-C activation due to rearrangements, which leave intact at least exons 1-3 of the gene that code for the AT hook domains (Kazmierczak et al, 1996b; Rogalla et al, 1996). Breakpoints outside (usually upstream) of the coding region of $\mathrm{HMGl}-\mathrm{C}$ have also been identified with chromosome aberrations mapped to the HMGI-C locus (Kazmierczak et al, 1999; Schoenberg Fejzo et 

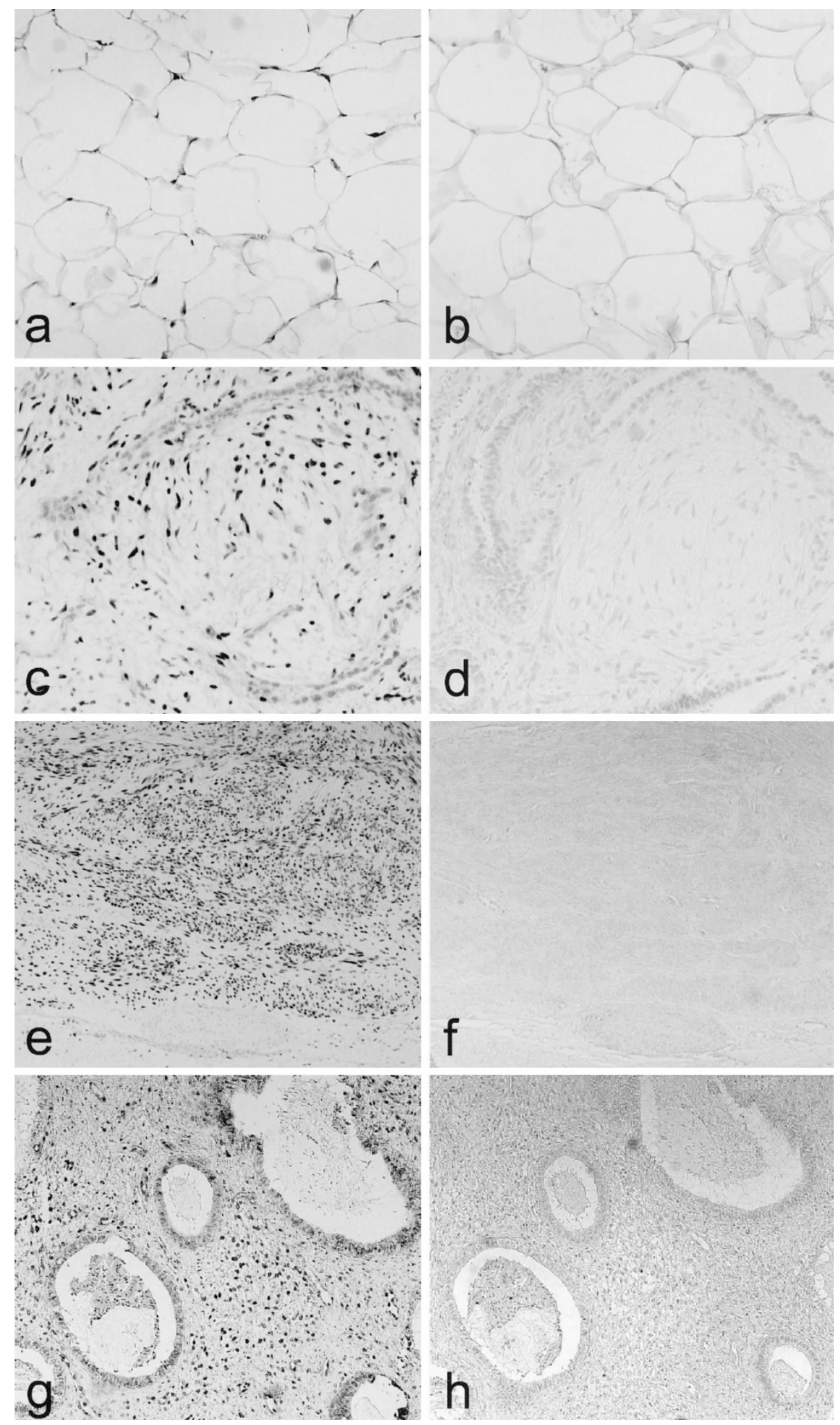

\section{Figure 1.}

a, Nuclear reactivity for HMGI-C in the neoplastic adipocytes of a lipoma (case 17L); $t(2 ; 12)(q 35 ; q 15)$ was identified in the tumor karyotype, FISH analysis was not performed. $b$, The corresponding immunohistochemical stain for $\mathrm{HMGI}(\mathrm{Y})$ is negative (case $17 \mathrm{~L}$ ). $c$, Positive nuclear reactivity for $\mathrm{HMGI}(\mathrm{Y})$ in the mesenchymal cells of a pulmonary chondroid hamartoma (case 11P); $\mathrm{t}(6 ; 10)(\mathrm{p} 21.3 ; \mathrm{q} 22.3)$ was identified in the tumor karyotype (Fig. 2d), FISH analysis results are illustrated in Figure $2 \mathrm{c}$ and are compatible with $\mathrm{HMGI}(Y)$ gene rearrangement. $d$, The corresponding immunohistochemical stain for $\mathrm{HMGI}(\mathrm{Y})$ is negative (case 11P). e, Nuclear reactivity for $\mathrm{HMGI}(\mathrm{Y})$ in the neoplastic smooth muscle cells of an uterine leiomyoma (case 1M); $\mathrm{t}(6 ; 14)(\mathrm{p} 21 ; \mathrm{q} 24)$ was identified in the tumor karyotype; FISH analysis results are compatible with $H M G I(Y)$ gene rearrangement. $f$, The corresponding immunohistochemical stain for HMGI-C is negative (case $1 \mathrm{M}$ ). $g$, Nuclear reactivity for HMGI-C in the stromal component of an endometrial polyp (case 10E); $\mathrm{t}(12 ; 14)(\mathrm{q} 15 ; \mathrm{q} 24-25)$ was identified in the tumor karyotype; FISH analysis results are compatible with HMGI-C gene rearrangement. The corresponding immunohistochemical stain for HMGI(Y) is negative (case 10E). 

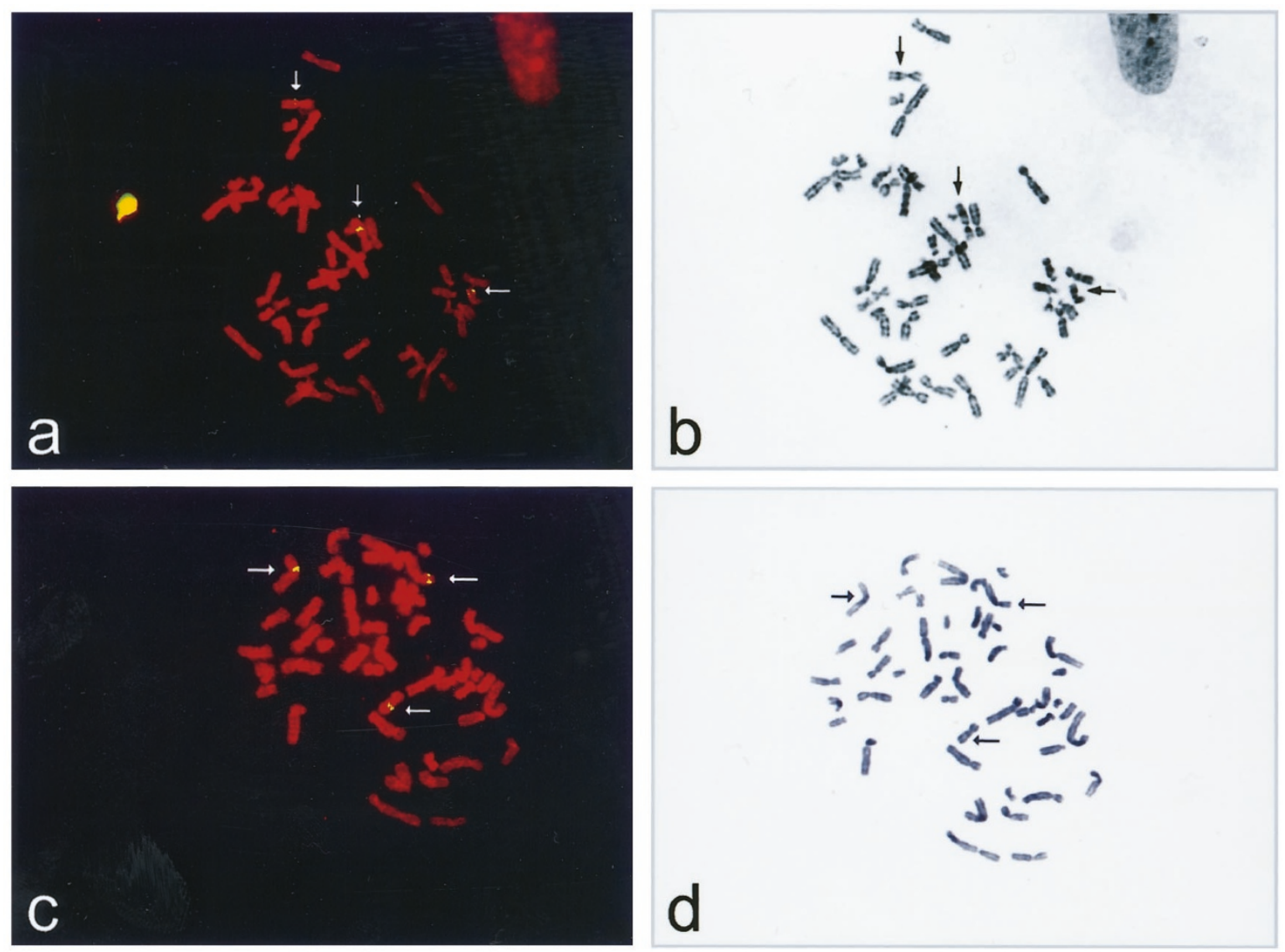

\section{Figure 2.}

a, Localization of a pool of cosmids (RM 133, RM 76, RM 53) spanning the HMGI-C gene in a metaphase spread of a pulmonary chondroid hamartoma (case 12P). Signals are seen on the normal chromosome 12, and the derivative chromosomes 12 and 16 (arrows). b, GTG banding was performed on the same metaphase spread prior to FISH. c, Localization of PAC 8603 spanning the breakpoint region 6p21.3 and containing the complete HMGI(Y) sequence in a metaphase spread of a pulmonary chondroid hamartoma (case 11P). Signals are seen on the normal chromosome 6, and the derivative chromosomes 6 and 10 (arrows). d, GTG banding of the same metaphase spread was performed prior to FISH.

al, 1996; Wanschura et al, 1996). HMGI-C amplification has been recently documented in a benign endometrial polyp characterized cytogenetically by double minute chromosomes (Dal Cin et al, 1998b). In the tumors with $H M G I(Y)$ rearrangement, most of the breakpoints are located outside the coding portions of the gene (usually downstream) (Kazmierczak et al, 1996c; 1998b; 1999; Tkachenko et al, 1997; Williams et al, 1997). This may indicate that the replacement of negative regulatory sequences by enhancers from the translocation partners is the likely molecular mechanism for HMGI(Y) dysregulation (Kazmierczak et al, 1998b). At variance with what is observed for HMGI-C, only one chimeric fusion transcript due to an intragenic rearrangement of $H M G I(Y)$ has been identified to date (Xiao et al, 1997).

Despite the abundant evidence for HMGI-C and $H M G I(Y)$ dysregulation in the benign tumors discussed above, few studies have documented whether rearrangement of the HMGI genes actually results in aberrant (over)expression of the corresponding protein (Dal Cin et al, 1998b; Tallini et al, 1997; Williams et al, 1997). Our study clearly demonstrates that $H M G I-C$ and $H M G I(Y)$ are commonly expressed in lipomas, pulmonary chondroid hamartomas, uterine leiomyo- mas, and endometrial polyps. Both genes are not expressed at any significant level in mature cells (Chiappetta et al, 1996; Gattas et al, 1999; Manfioletti et al, 1991; Rogalla et al, 1996), and it has been shown that proliferating non-transformed cells express markedly lower HMGI(Y) (Bussemakers et al, 1991; Ram et al, 1993) or HMGl-C (Berlingieri et al, 1995) levels compared with their transformed counterpart. However, both proteins were commonly detected in the tumors analyzed in this study, all are benign and slow growing, while no significant immunoreactivity was seen in the perilesional portions of normal tissue. In addition, the immunohistochemical detection of HMGI-C and HMGI(Y) remarkably correlated with the type of alteration detected by conventional chromosome analysis at $12 \mathrm{q} 15$ and $6 \mathrm{p} 21$ and/or by FISH using probes for HMGI-C and HMGI(Y). The association between immunohistochemical results and genetic changes is significant both in general terms for the entire pool of cases analyzed as well as within each tumor category. This correlation indicates that the aberrant (over)expression of HMGI-C and HMGI(Y) is not simply the result of increased cellular proliferation but that it is related to the specific molecular changes that accompany the chromosomal rear- 
rangement. It also shows that the majority of the rearrangements are in frame and that the resulting mRNAs are translated into detectable protein levels, thus supporting a possible role of HMGI-C and $H M G I(Y)$ in tumor growth. FISH analysis with microclone probes spanning the HMGI-C and HMGI(Y) loci allows the discrimination between cases with intragenic breaks and those with breakpoints located outside of the gene, either upstream or downstream (Dal Cin et al, 1998a; Kazmierczak et al, 1996b; 1998b; 1999; Schoenmakers et al, 1995). Although measurements of the precise amount of tissue immunoreactivity could not be reliably estimated, comparison with the immunohistochemical results indicates that HMGI-C or HMGI(Y) expression is not significantly different regardless of whether the breakpoints are located inside or outside (5' - or $3^{\prime}-$ ) of the gene (data not shown).

Genetic $H M G$ alterations were not accompanied by detectable $\mathrm{HMGI}-\mathrm{C}$ and $\mathrm{HMGI}(\mathrm{Y})$ immunoreactivity in approximately $5-10 \%$ of the tumors. This may be explained by an increase in protein expression below the sensitivity of the immunohistochemical analysis, by the presence of a fusion protein too abnormal to be recognized with the antibodies used for the study, by sample bias, or by a combination of the above. However, tissue immunoreactivity for HMGI-C and $\mathrm{HMGI}(\mathrm{Y})$ was observed in approximately $20 \%$ of the cases lacking cytogenetic evidence of $12 q 15$ or 6 p21, possibly due to defective cell growth for karyotyping or by the presence of cryptic rearrangements, as previously shown in pulmonary chondroid hamartomas (Kazmierczak et al, 1996a), uterine leiomyomata (Williams et al, 1997), and endometrial polyps (Wanschura et al, 1997). Analogous to what was observed for Cyclin D1 expression in mantle cell lymphoma (de Boer et al, 1995; 1997), gene expression as detected by immunohistochemistry may be more sensitive than cytogenetics as a marker for gene dysregulation. In addition to high sensitivity, immunohistochemistry offers the advantage of allowing in situ tissue discrimination with the possibility of identifying the specific cell types in which HMGI-C and HMGI(Y) are aberrantly expressed. This is particularly relevant because lesions such as endometrial polyps and pulmonary chondroid hamartomas include both epithelial as well as mesenchymal components. In both tumor types it was the immunoreactivity observed in the mesenchymal cells that consistently paralleled the cytogenetic findings, thus confirming previous observations on the pivotal role of stromal cells in the development of pulmonary chondroid hamartomas (Fletcher et al, 1992a) and endometrial polyps (Fletcher et al, 1992b). Distinct nuclear HMGI protein immunoreactivity was observed in some of the endometrial glands as well as in occasional epithelial cells in pulmonary chondroid hamartomas. HMGI protein immunoreactivity in these cells did not correlate with chromosomal alterations and may represent a nonspecific result of increased proliferation or a response to microenvironmental influences (Gattas et al, 1999). At least focal HMGI-C and $\mathrm{HMGI}(\mathrm{Y})$ immunoreactivity was observed in endo- metrial control samples in which immunohistochemical reactivity was associated with endometrial glands exhibiting proliferative features. Interestingly, HMGI-C was detected by RTPCR in 2 of 10 myometrial samples in the study by Rogalla et al (1996) and, although this may have been due to the presence of leiomyomata too small to be identified at the time of tissue collection (Rogalla et al, 1996), it can not be excluded that the HMGI-C positivity was in fact due to contamination of the specimens by proliferative endometrium. Focal HMGI protein immunoreactivity was also seen in the pneumocytes of non-neoplastic lung tissue controls, a finding that is consistent with the RTPCR detection of $\mathrm{HMGl}-\mathrm{C}$ in normal adult lung samples (Gattas et al, 1999). These observations indicate that although both $\mathrm{HMGI}-\mathrm{C}$ and $\mathrm{HMGI}(\mathrm{Y})$ are generally not expressed at any significant level in normal adult tissues (Chiappetta et al, 1996; Rogalla et al, 1996; Gattas et al, 1999), their expression may be upregulated, presumably as a result of non-neoplastic cellular proliferation or microenvironmental factors. Although low level expression of $\mathrm{HMGI}(\mathrm{Y})$ in adult tissue has been documented (Chiappetta et al, 1996), these findings require further study, particularly in the light of recent observations reporting increased HMGI-C levels in normal in vitro cultured cells (Gattas et al, 1999).

In conclusion, this study shows that expression of $\mathrm{HMGI}-\mathrm{C}$ and $\mathrm{HMGI}(\mathrm{Y})$ is a common occurrence in those benign human tumors carrying chromosome abnormalities at $12 q 15$ and 6 p21 and that their expression pattern is compatible with the postulated rearrangements involving $\mathrm{HMGI}-\mathrm{C}$ and $\mathrm{HMGI}(\mathrm{Y})$ genes. It also supports the view that in biphasic lesions composed of a mixture of both stromal and epithelial cells, the mesenchymal component is the site of the HMGl genetic alterations and abnormal gene expression. Further investigation of disregulated HMGI expression in cytogenetically abnormal human tumors may contribute to a better understanding of the role that is played by HMGI proteins in normal and abnormal cellular growth and development.

\section{Materials and Methods}

\section{Selection of Cases}

A group of 95 human tumors was analyzed. They constitute a representative sample of the benign lesions in which karyotypic rearrangements at 6p21 and/or 12q15 are commonly detected (Mitelman, 1998) and included 21 pulmonary chondroid hamartomas, 20 lipomas, 26 uterine leiomyomata, and 28 endometrial polyps. These tumors were chosen to include lesions with 6p21 or 12q15 rearrangements as well as cases with seemingly normal karyotypes and cases with alterations not involving 6 p21 or $12 q 15$ for each tumor type.

\section{Cytogenetic and Molecular Cytogenetic Analysis}

Conventional chromosomal analysis was performed after short-term culture by G-banding in the cytoge- 
netic laboratories of the universities of Leuven (Belgium) (43 cases), Bremen (Germany) (21 cases), and Cagliari (Italy) (31 cases). All tumors were successfully karyotyped and included lesions with 6p21 $(n=17)$ or $12 q 15$ alterations $(n=33)$, karyotypic alterations not involving $6 \mathrm{p} 21$ or $12 \mathrm{q} 15(n=13)$, or a normal karyotype $(n=32)$. FISH was performed after GTG banding of the same metaphase spreads according to previously published procedures (Kievits et al, 1992). Metaphases were hybridized with a pool of different cosmids spanning over the breakpoint region $12 q 15$ and flanking the third intron of HMGI-C (Dal Cin et al, 1998a; Kazmierczak et al, 1996b) and with PAC clones containing the HMGI(Y) gene mapped at 6p21.2 (Kazmierczak et al, 1996c). In translocations affecting HMGI-C or HMGI(Y), hybridization signals were observed on the derivative chromosomes and/or on the translocation partners of chromosomes 12 or 6 , respectively. In the case of peri- or paracentric inversions of chromosomes 12 or 6 , split signals on the short and the long arm or a double signal on one arm was observed. Cytogenetic and FISH analysis data were compiled independently of the immunohistochemical results and, for many of the cases, have been previously reported (Dal Cin et al, 1995; 1998a; 1998b; Kazmierczak et al, 1996b; 1999; Wanschura et al, 1995).

\section{Immunohistochemistry}

Representative routinely processed paraffinembedded blocks from the selected cases were obtained from the pathology laboratories of the medical centers in Leuven (Belgium), Eindhoven (Holland), Bremen (Germany), and Cagliari (Italy). Histology sections were cut and immunostained according to established protocols using an avidin-biotinylated peroxidase complex $(\mathrm{ABC})$ technique previously described (Tallini et al, 1997). The HMGI-C antibodies were raised in rabbits against the recombinant murine $\mathrm{HMGl}-\mathrm{C}$ protein, and, because of the high degree of homology between mouse and human HMGI-C, they also recognize the human protein. The HMGI-C antibodies were used at a 1:400 dilution. Before incubation, histology sections were pretreated with $0.6 \mathrm{mg}$ Pronase (Sigma, St. Louis, Missouri) for $5^{\prime}$ (Tallini et al, 1997). The antibodies against HMGI(Y) were developed against a HMGI(Y)-specific synthetic peptide corresponding to the $\mathrm{NH}_{2}{ }^{-}$terminal portion of the molecule (Chiappetta et al, 1995). They were used at a 1:100 dilution. For optimal results, the concentration of the HMGI-C and HMGI(Y) antibodies in a minority of cases had to be tailored to take into account differences in tissue processing and preservation methods among the different pathology departments. No significant cross-reactivity was observed between $\mathrm{HMGI}(\mathrm{Y})$ and HMGI-C. Negative controls were performed by omitting the primary antibody or by incubating the histology sections with an unrelated nuclear antibody against Human Papilloma Virus (Dako Corporation, Glostrup, Denmark), according to the specifications provided by the manufacturer. Examination of perilesional normal tissue provided a built in negative control for most of the cases analyzed. In addition, 10 samples of previously karyotyped normal endometrium as well as seven samples of non-neoplastic lung tissue were also investigated. Immunohistochemistry results were analyzed without knowledge of the cytogenetic data. Only those cases in which there was positive nuclear staining in more than $10 \%$ of the tumor cells were scored as positive. The significance of the immunohistochemical findings was statistically evaluated. The Fisher's Exact test was used to determine the association between HMGI-C or HMGI(Y) reactivity and $6 \mathrm{p} 21$ or $12 \mathrm{q} 13-15$.

\section{References}

Ashar HR, Schoenberg Fejzo M, Tkachenko A, Zhou X, Fletcher JA, Weremowicz S, Morton CC, and Chada K (1995). Disruption of the architectural factor HMGI-C: DNA-binding AT hook motifs fused in lipomas to distinct transcriptional regulatory domains. Cell 82:57-65.

Bandiera A, Bonifacio D, Manfioletti G, Mantovani F, Rustighi A, Zanconati F, Fusco A, Di Bonito L, and Giancotti V (1998). Expression of $\mathrm{HMGI}(\mathrm{Y})$ proteins in squamous intraepithelial and invasive lesions of the uterine cervix. Cancer Res 58: 426-431.

Berlingieri MT, Manfioletti G, Santoro M, Bandiera A, Visconti R, Giancotti V, and Fusco A (1995). Inhibition of HMGI-C protein synthesis suppresses retrovirally induced neoplastic transformation of rat thyroid cells. Mol Cell Biol 15:15451553.

Bussemakers MJG, van de Ven WJM, Debruyne FMJ, and Schalken JA (1991). Identification of high mobility group protein I $(Y)$ as potential progression marker for prostate cancer by differential hybridization analysis. Cancer Res 51:606-611.

Chiappetta G, Avantaggiato V, Visconti R, Fedele M, Battista S, Trapasso F, Merciai BM, Fidanza V, Giancotti V, Santoro M, Simeone A, and Fusco A (1996). High level expression of the HMGI $(Y)$ gene during embryonic development. Oncogene 13:2439-2446.

Chiappetta G, Bandiera A, Berlingieri MT, Visconti R, Manfioletti G, Battista S, Martinez-Tello FJ, Santoro M, Giancotti $V$, and Fusco A (1995). The expression of the high mobility group HMGI $(Y)$ proteins correlates with the malignant phenotype of human thyroid neoplasms. Oncogene 10:13071314.

Chiappetta G, Tallini G, DeBiasio MC, Manfioletti G, Martinez-Tello FJ, Pentimalli F, de Nigris F, Mastro A, Botti G, Fedele M, Berger N, Santoro M, Giancotti V, Fusco A (1998). Detection of high mobility group I HMGI(Y) protein in the diagnosis of thyroid tumors: HMGI(Y) expression represents a potential diagnostic indicator of carcinoma. Cancer Res 58:4193-4198.

Dal Cin P, Timmerman D, Van den Berghe I, Wanschura S, Kazmierczak B, Vergote I, Deprest J, Neven P, Moerman P, Bullerdiek J, and Van den Berghe H (1998a). Genomic changes in endometrial polyps associated with tamoxifen show no evidence for its action as an external carcinogen. Cancer Res 58:2278-2281. 
Dal Cin P, Vanni R, Marras R, Moerman P, Kools P, Andria M, Valdes E, Deprest J, Van de Ven W, and Van den Berghe H (1995). Four cytogenetic subgroups can be identified in endometrial polyps. Cancer Res 55:1565-1568.

Dal Cin P, Wanschura S, Kazmierczak B, Tallini G, Dei Tos A, Bullerdiek J, Van den Berghe I, Moerman P, and Van den Berghe $H$ (1998b). Amplification and expression of the HMGIC gene in a benign endometrial polyp. Genes, Chromosom, Cancer 22:95-99.

de Boer CJ, Schuuring E, Dreef E, Peters G, Bartek J, Kluin PM, and van Krieken JH (1995). Cyclin D1 protein analysis in the diagnosis of mantle cell lymphoma. Blood 86:2715-2723.

de Boer CJ, van Krieken JH, Schuuring E, and Kluin PM (1997). Bcl-1/cyclin D1 in malignant lymphoma. Ann Oncol 8:109-117.

Fedele M, Bandiera A, Chiappetta G, Battista S, Viglietto G, Manfioletti G, Casamassimi A, Santoro M, Giancotti V, and Fusco A (1996). Human colorectal carcinomas express high levels of high mobility group HMGI(Y) proteins. Cancer Res 56:1896-1901.

Fletcher JA, Pinkus GS, Donavan K, Naeem R, Sugarbaker DJ, Mentzer S, Pinkus JL, and Longtine J (1992a). Clonal rearrangement of band 6p21 in the mesenchymal component of pulmonary chondroid hamartoma. Cancer Res 52:6224-6228.

Fletcher JA, Pinkus JL, Lage JM, Morton CC, and Pinkus GS (1992b). Clonal 6p21 rearrangement is restricted to the mesenchymal component of an endometrial polyp. Genes Chromosom Cancer 5:260-263.

Friedmann M, Holth LT, Zoghbi HY, and Reeves R (1993). Organization, inducible-expression and chromosome localization of the human HMG-I(Y) nonhistone protein gene. Nucleic Acids Res 21:4259-4267.

Gattas GJ, Quade BJ, Nowak RA, and Morton CC (1999). HMGIC expression in human adult and fetal tissues and in uterine leiomyomata. Genes Chromosom Cancer 25:316-22.

Giancotti V, Buratti E, Perissin L, Zorzet S, Balmain A, Portella G, Fusco A, and Goodwin GH (1989). Analysis of the HMGI nuclear proteins in mouse neoplastic cells induced by different procedures. Exp Cell Res 184:538-545.

Giancotti V, Pani B, D'Andrea P, Berlingieri MT, Di Fiore PP, Fusco A, and Vecchio G (1987). Elevated levels of a specific class of nuclear phosphoproteins in cells transformed with ras and v-mos oncogenes and by co-transfection with c-myc and polyoma middle T genes. EMBO J 6:1981-1987.

Hirning-Folz U, Wilda M, Rippe V, Bullerdiek J, and Hameister H (1998). The expression pattern of the HMGIC gene during development. Genes, Chromosom Cancer 23:350-357.

Kazmierczak B, Dal Cin P, Wanschura S, Bartnitzke S, Van den Berghe H, and Bullerdiek J (1998a). Cloning and molecular characterization of part of a new gene fused to HMGIC in mesenchymal tumors. Am J Pathol 152:431-435.

Kazmierczak B, Dal Cin P, Wanschura S, Borrmann L, Fusco A, Van den Berghe $H$, and Bullerdiek J (1998b). HMGIY is the target of $6 \mathrm{p} 21.3$ rearrangements in various benign mesenchymal tumors. Genes, Chromosom Cancer 23:279-285.

Kazmierczak B, Hennig Y, Wanschura S, Rogalla P, Bartnitzke S, Van de Ven W, Bullerdiek J (1995a). Description of a novel fusion transcript between $\mathrm{HMGl}-\mathrm{C}$, a gene encoding for a member of the high mobility group proteins, and the mitochondrial aldehyde dehydrogenase gene. Cancer Res 55:6038-6039.
Kazmierczak B, Meyer-Bolte K, Tran KH, Wöckel W, Breightman I, Rosigkeit J, Bartnitzke S, Bullerdiek J (1999). A high frequency of tumors with rearrangements of genes of the HMGI(Y) family in a series of 191 pulmonary chondroid hamartomas. Genes Chromosom Cancer 26:125-133.

Kazmierczak B, Pohnke Y, and Bullerdiek J (1996a). Fusion transcripts between the HMGI-C gene and RTVLH-related sequences in mesenchymal tumors without cytogenetic aberrations. Genomics 38:223-226.

Kazmierczak B, Rosigkeit J, Wanschura S, Meyer-Bolte K, Van de Ven WJM, Kayser K, Krieghoff B, Hastendiek H, Bartnitzke S, Bullerdiek J (1996b). HMGI-C rearrangements as the molecular basis for the majority of pulmonary chondroid hamartomas: a survey of 30 tumors. Oncogene 12:515521.

Kazmierczak B, Wanschura S, Meyer-Bolte K, Cavelitz J, Meister P, Bartnitzke S, and Van de Ven W (1995b). Cytogenetic and molecular analysis of an aggressive angiomyxoma. Am J Pathol 147:580-585.

Kazmierczak B, Wanschura S, Rommel B, Bartnitzke S, and Bullerdiek J (1996c). Ten pulmonary chondroid hamartomas with chromosome 6 p21 breakpoints within the HMG-I(Y) gene or its immediate surroundings. J Natl Cancer Inst 88:1234.

Kievits T, Dauwerse JG, Wiegant J, Devilee P, Breuning MH, Cornelisse CJ, van Ommen G, and Pearson PL (1992). Rapid chromosomal localization of cosmids by using nonradioactive in situ hybridization. Cytogenet Cell Genet 53: $134-135$.

Manfioletti G, Giancotti V, Bandiera A, Buratti E, Sautiere P, Cary P, Crane-Robinson C, Coles B, and Goodwin GH (1991). cDNA cloning of the HMGI-C phosphoprotein, a nuclear protein associated with neoplastic and undifferentiated phenotypes. Nucleic Acids Res 19:6793-6797.

Mitelman F (1998). Catalog of chromosomal aberration in cancer (6th ed)., New York: Wiley Liss.

Petit MMR, Mols R, Schoenmakers EFPM, Mandahl N, and Van De Ven WJM (1996). LPP, the preferred fusion partner gene of HMGIC in lipomas, is a novel member of the LIM protein gene family. Genomics 36:118-129.

Rabbitts TH (1994). Chromosomal translocations in human cancer. Nature 372:143-149.

Ram TG, Reeves R, and Hosick HL (1993). Elevated high mobility group $\mathrm{I}(\mathrm{Y})$ gene expression is associated with progressive transformation of mouse mammary epithelial cells. Cancer Res 53:2655-2660.

Rogalla P, Drechsler K, Frey G, Hennig Y, Helmke B, Bonk U, and Bullerdiek J (1996). HMGI-C expression patterns in human tissues. Implications for the genesis of frequent mesenchymal tumors. Am J Pathol 149:775-779.

Rogalla P, Drechsler K, Kazmierczak B, Rippe V, Bonk U, and Bullerdiek J (1997). Expression of HMGI-C a member of the high mobility group protein family, in a subset of breast cancers: relationship to histologic grade. Mol Carcinogen 19:153-156.

Rommel B, Rogalla P, Jox A, Kalle CV, Kazmierczak B, Wolf $\mathrm{J}$, and Bullerdiek $\mathrm{J}$ (1997). HMGI-C, a member of the high mobility group family of proteins is expressed in hematopoietic stem cells and leukemic cells. Leuk Lymphoma 26:603607. 
Schoenberg Fejzo M, Ashar HR, Krauter KS, Powell WL, Rein MS, Weremowicz S, Yoon S-Y, Kucherlapati RS, Chada K, and Morton CC (1996). Translocation breakpoints upstream of the HMGIC gene in uterine leiomyomata suggest dysregulation of this gene by a mechanism different from that in lipomas. Genes Chromosom Cancer 17:1-6.

Schoenmakers EFPM, Wanschura S, Mols R, Bullerdiek J, Van den Berghe H, and Van de Ven WJM (1995). Recurrent rearrangements in the high mobility group protein gene, HMGI-C, in benign mesenchymal tumours. Nature Genet 10:436-444.

Staats B, Bonk U, Wanschura S, Hanisch P, Schoenmakers EFPM, Van de Ven WJM, Bartnitzke S, and Bullerdiek J (1996). A fibroadenoma with a $t(4 ; 12)(q 27 ; q 15)$ affecting the HMGI-C gene, a member of the high mobility group protein gene family. Breast Cancer Res Treat 38:299-308.

Tallini G, Dal Cin P, Rhoden KR, Chiappetta G, Manfioletti G, Giancotti V, Fusco A, Van den Berghe H, Sciot R (1997). Expression of HMGI-C and HMGI(Y) in ordinary lipoma and atypical lipomatous tumors. Immunohistochemical reactivity correlates with karyotypic alterations. Am J Pathol 151:3743.

Tamimi Y, van der Poel HG, Denyn M-M, Umbas R, Karthaus HFM, Debruyne FMJ, and Schalken JA (1993). Increased expression of high mobility group protein I $(Y)$ in high grade prostatic cancer determined by in situ hybridization. Cancer Res 53:5512-5516.

Tkachenko A, Ashar HR, Meloni AM, Sandberg AA, and Chada KK (1997). Misexpression of disrupted HMGI architectural factors activates alternative pathways of tumorigenesis. Cancer Res 57:2276-2280.
Wanschura S, Dal Cin P, Kazmierczak B, Barnitze S, Van den Berghe H, and Bullerdiek J (1997). Hidden paracentric inversions of chromosome arm 12q affecting the HMGl-C gene. Genes Chromosom Cancer 18:322-323.

Wanschura S, Kazmierczak B, Pohnke Y, Meyer-Bolte K, Bartnitzke S, Van de Ven WJM, Bullerdiek J (1996). Transcriptional activation of HMGI-C in three pulmonary hamartomas each with a der(14) $\mathrm{t}(12 ; 14)$ as the sole cytogenetic abnormality. Cancer Letters 102:17-21.

Wanschura S, Kazmierczak B, Schoenmakers EFPM, Meyen E, Bartnitzke S, Van de Ven WJM, Bullerdiek J, and Schloot W (1995). Regional fine mapping of the multiple aberration region involved in uterine leiomyomas, lipomas and pleomorphic adenomas of the salivary gland to $12 q 15$. Genes Chromosom Cancer 14:68-70.

Williams AJ, Powell WL, Collins T, and Morton CC (1997). HMGI(Y) expression in human uterine leiomyomata. Involvement of another high-mobility group architectural factor in a benign neoplasm. Am J Pathol 150:911-918.

Xiao S, Lux ML, Reeves R, Hudson TJ, and Fletcher JA (1997). HMGI(Y) activation by chromosome 6p21 rearrangements in multilineage mesenchymal cells from pulmonary hamartoma. Am J Pathol 150:901-910. 